2001s-21

\title{
Unemployment Insurance and Subsequent Job Duration: Job Matching vs Unobserved Heterogeneity
}

Christian Belzil

Série Scientifique

Scientific Series

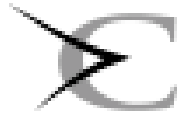




\section{CIRANO}

Le CIRANO est un organisme sans but lucratif constitué en vertu de la Loi des compagnies du Québec. Le financement de son infrastructure et de ses activités de recherche provient des cotisations de ses organisationsmembres, d'une subvention d'infrastructure du ministère de la Recherche, de la Science et de la Technologie, de même que des subventions et mandats obtenus par ses équipes de recherche.

CIRANO is a private non-profit organization incorporated under the Québec Companies Act. Its infrastructure and research activities are funded through fees paid by member organizations, an infrastructure grant from the Ministère de la Recherche, de la Science et de la Technologie, and grants and research mandates obtained by its research teams.

\section{Les organisations-partenaires / The Partner Organizations}

•École des Hautes Études Commerciales

-École Polytechnique

-Université Concordia

-Université de Montréal

-Université du Québec à Montréal

-Université Laval

-Université McGill

-MEQ

-MRST

-Alcan inc.

-AXA Canada

-Banque du Canada

- Banque Laurentienne du Canada

-Banque Nationale du Canada

-Banque Royale du Canada

-Bell Québec

-Bombardier

-Bourse de Montréal

-Développement des ressources humaines Canada (DRHC)

-Fédération des caisses populaires Desjardins de Montréal et de l'Ouest-du-Québec

-Hydro-Québec

-Imasco

-Industrie Canada

-Pratt \& Whitney Canada Inc.

-Raymond Chabot Grant Thornton

-Ville de Montréal

(C) 2001 Christian Belzil. Tous droits réservés. All rights reserved.

Reproduction partielle permise avec citation du document source, incluant la notice $\odot$.

Short sections may be quoted without explicit permission, if full credit, including $\odot$ notice, is given to the source.

Ce document est publié dans l'intention de rendre accessibles les résultats préliminaires

de la recherche effectuée au CIRANO, afin de susciter des échanges et des suggestions.

Les idées et les opinions émises sont sous l'unique responsabilité des auteurs, et ne représentent pas nécessairement les positions du CIRANO ou de ses partenaires.

This paper presents preliminary research carried out at CIRANO and aims at encouraging discussion and comment. The observations and viewpoints expressed are the sole responsibility of the authors. They do not necessarily represent positions of CIRANO or its partners. 


\title{
Unemployment Insurance and Subsequent Job Duration: Job Matching vs Unobserved Heterogeneity*
}

\author{
Christian Belzil
}

\section{Résumé / Abstract}

Dans cet article, j'analyse le lien entre la durée des prestations d'assurancechômage, la durée du chômage et la durée de l'emploi subséquent. L'analyse est faite à l'aide d'un modèle de durée avec états multiples et hétérogénéité nonobservée. À l'aide du modèle, je tente de faire la distinction entre deux hypothèses possibles qui expliqueraient la corrélation négative entre durée de chômage et durée de l'emploi subséquent; la durée des prestations augmente la durée de l'emploi subséquent (un effet de matching), ou la corrélation négative est expliquée par la sélection adverse. Les résultats tendent à supporter l'hypothèse de sélection adverse tandis que l'effet de matching semble être faible.

The relationship between Unemployment Insurance (UI) benefit duration, unemployment duration and subsequent job duration is investigated using a multistate duration model with state specific unobserved heterogeneity. I examine two potential explanations for the negative correlation between unemployment and job spell durations; UI benefits increase job matching quality (the "Matching" effect) vs unobserved heterogeneity ("Adverse Selection"). The Matching effect is found to be weak. Although new jobs accepted within 5 weeks of benefit termination seem to have a higher dissolution rate, the negative correlation between unemployment and job duration is mostly explained by unobserved heterogeneity. Various simulations indicate that increasing the maximum benefit duration by one week will raise expected unemployment duration by 1.0 to 1.5 days but will raise expected job duration by 0.5 to 0.8 days only.

Mots Clés : $\quad$ Assurance-chômage, matching de l'emploi, durée du chômage, durée de l'emploi

Keywords: Unemployment insurance, job matching, unemployment duration, job duration

\footnotetext{
* Corresponding Author: Christian Belzil, CIRANO, 2020 University Street, 25 ${ }^{\text {th }}$ floor, Montréal, Qc, Canada H3A 2A5 Tel.: (514) 985-4000 Fax: (514) 985-4039 email: belzilc@ cirano.qc.ca This is a revised version of the paper "Contiguous Duration Dependence and Nonstationarity in Job Search". I would like to thank Thierry Magnac, John Rust (the Editor), Chris Taber and an anonymous referee for helpful comments and suggestions. The usual disclaimer applies.
}

$\dagger$ Concordia University and CIRANO 


\section{Introduction}

The effect of Unemployment Insurance (UI) on the labor market is one of the most active areas of research in modern labor economics. The payment of UI benefits increases the welfare of risk averse workers affected by adverse employment shocks and raises their reservation wages. As a consequence, UI is expected to raise the duration of unemployment. At the same time, the payment of unemployment compensation can introduce strong disincentive effects in the labor market. In particular, the payment of UI benefits can sometimes induce the unemployed to reduce their search intensity. ${ }^{1}$

While the positive correlation between UI benefit generosity and unemployment duration is well established at the empirical level, whether it is caused mostly by a decrease in search intensity or an increase in reservation wages remain an open question. ${ }^{2}$ The effect of UI on the labor market is not limited to unemployment duration only. UI can also affect subsequent job duration. Since benefit generosity is expected to raise reservation wages of the unemployed, it should therefore affect the quality of subsequent job matches. ${ }^{3}$ Although the effects of UI on unemployment duration is relatively well documented, very little is known about the effects of UI on the quality of labor market adjustments. This paper proposes an analysis of the effects of UI benefit duration from an angle which has, so far, been neglected in the literature. The empirical analysis is based on the idea that UI benefits should not only affect the escape rate out of unemployment but also subsequent job duration. If increases in the escape rate out of unemployment are explained by significant decreases in reservation wages, those who are close to benefit termination might accept jobs which they are likely to quit in the future. In other words, given a certain level of benefit duration, those who leave unemployment earlier (with a longer potential benefit duration ahead)

\footnotetext{
${ }^{1}$ For a theoretical analysis of moral hazard and Unemployment Insurance, see Hopenhayn and Nicolini (1997).

${ }^{2}$ Meyer (1990) and Han and Hausman (1990) have found a significant increase (spikes) in the escape rate out of unemployment when unemployment benefits lapse. This might suggest that search intensity increases substantially shortly before benefit termination.

${ }^{3}$ Although most efforts devoted to the effects of UI on labor markets have concentrated on the duration of unemployment, early attempts to capture the impact of UI on the labor markets seem to have focused on the effects of UI benefits on re-employment earnings (see Ehrenberg and Oaxaca, 1976 or Classen, 1977). To my knowledge, Belzil (1990) is the first empirical analysis of the effects of UI on job/employment stability.
} 
will experience better job matches. Assuming that better job matches are less likely to dissolve, accepted job durations should be sensitive to UI benefit duration. I refer to this effect as the "Matching" hypothesis. The Matching hypothesis is a type of structural state/duration dependence which implies a negative correlation between unemployment durations and subsequent job durations.

An alternative explanation for the correlation between UI benefit duration and subsequent job duration is the "Adverse Selection" hypothesis. Adverse selection can arise from unobserved characteristics of individuals (unobserved heterogeneity) and is commonly believed to result in a negative correlation between unemployment duration and subsequent job durations. That is, some individuals may have attributes that make them less attractive to employers but which are not observed by the econometrician. These individuals are more likely to have longer unemployment spells and shorter subsequent job durations. If one fails to control for this type of unobserved heterogeneity, there is a danger of "spurious state dependence" that could result in the finding that longer unemployment durations imply shorter subsequent job durations. In this paper I attempt to control for unobserved heterogeneity in order to avoid making spurious inferences about the relationship between unemployment duration and subsequent job duration. By conditioning on a person's unobserved type, I can assess whether there is indeed a structural relationship between unemployment duration and subsequent job duration or only a spurious one. Given data on both unemployment duration and job duration and information on benefit duration, identifying the "Matching" effect from pure unobserved heterogeneity is therefore relatively simple. For a set of individuals entitled to the same maximum benefit duration (say 0 for the sake of the argument), the observed correlation between job duration and unemployment duration can be used to infer the importance of the Adverse Selection Hypothesis. Conditional on a specific type, individual variations in benefit duration provide information on the marginal effects of benefit duration on both unemployment and subsequent job durations (the Matching hypothesis).

At the outset, I must say that subsequent job duration is only one of the potential measures of job match quality. However, for reasons discussed in Section 2, it is the one I focus on. To be consistent with the terminology used in the literature, I use the term "maximum benefit duration" to designate the initial benefit entitlement period (as measured at the start of 
the unemployment spell) and the term "potential benefit duration" to designate the number of weeks of benefit remaining at a given point in time (given elapsed unemployment duration). I use a multi-state hazard model to investigate how the subsequent job hazard function is related to unemployment duration as well as unemployment benefit duration. The model has 2 states (unemployment duration and accepted job duration). The empirical work is carried on Canadian data which come from administrative files of the Canadian UI program. ${ }^{4}$ More details are found in Section 3 and Section 4.

The results indicate that both hypotheses contribute to explain the observed correlation between unemployment duration and accepted job duration, although the Matching effect appears much weaker than the sorting effect explained by bi-variate unobserved heterogeneity. The Matching effec$\mathrm{t}$ seems to exist only within a short period before benefit termination. In particular, the escape rate out of unemployment seems to increase significantly within 5 weeks of benefit termination and new jobs accepted within this 5 week period seem to have a higher dissolution rate. At the same time, and after controlling for individual variations in benefit duration, there is a strong negative correlation between unobserved heterogeneity affecting unemployment duration and unobserved heterogeneity affecting subsequent job duration. As the Matching effect seems present only shortly before benefit termination, very few individuals would be affected by a counterfactual increase in benefit duration. The results of various simulations indicate that increasing the maximum benefit duration by one week would raise expected unemployment duration by 1.0 to 1.5 days but raise expected job duration by only 0.5 to 0.8 days.

The paper is organized as follows. In the next section (Section 2), I present some theoretical arguments which will be used as guidelines for the econometric model. In Section 3, I present the Canadian UI system. In Section 4, I describe the data and discuss the sampling method. The econometric specification is discussed in Section 5 while the results are in Section 6 . In Section 7, I simulate the effects of an increase in benefit duration on average unemployment duration and average accepted job duration. The conclusion is in Section 8.

\footnotetext{
${ }^{4}$ The administrative files of the Canadian UI program are now maintained by Human Resources Development Canada.
} 


\section{Job Search Theory and the Matching Ef- fect of UI}

The empirical analysis presented in this paper is based on the idea that nonstationary (decreasing) reservation wages create an identifiable dependence between completed duration, re-employment wages and subsequent job duration. In this section, I illustrate this idea using a simple job search model. The model is used as a guideline for the specification of the empirical model. The theoretical framework is as follows. Initially; a group of homogenous workers are laid off and search for a new job while unemployed. Elapsed unemployment duration is denoted $\tau_{u}$. They search for wages from a known (stationary) distribution function, $F(w)$.The wage $(w)$ is understood to be the sum of a monetary payment and a non-monetary component which could represent job quality. All individuals are entitled to UI benefit for a finite period (denoted $T$ ). Current benefit entitlement, given elapsed unemployment duration, $b\left(\tau_{u}\right)$, is described as follows:

$$
\begin{aligned}
& b\left(\tau_{u}\right)=\tilde{b} \text { when } \tau_{u} \leq T \\
& b\left(\tau_{u}\right)=0 \text { when } \tau_{u}>T
\end{aligned}
$$

Although it would be straightforward to introduce an exogenous layoff probability without changing the results, I assume that they are no layoffs. While unemployed, individuals receive at most one offer per period with probability $\lambda_{u}$. When employed, the offer probability is $\lambda_{e}$. With a finite benefit period, it is easy to show that the value of unemployed search, $V_{u}\left(b\left(\tau_{u}\right)\right)$, decreases monotonically until $T$ and remains constant beyond $T .{ }^{5}$ It is understood that $V_{u}\left(b\left(\tau_{u}\right)\right)$ represents the value of continuing search taking into account that search is possible upon re-employment. The value of accepting employment, at wage $\mathrm{w}$, is denoted $V_{e}(w)$. Clearly, $\mathrm{V}_{e}(w)$ is stationary and the escape rate out of unemployment, $\theta_{u}\left(\tau_{u}\right)$, is given by

$$
\theta_{u}\left(\tau_{u}\right)=\lambda_{u} \cdot\left\{1-F\left(w_{\tau_{u}}^{*}\right)\right\}
$$

where $w_{\tau_{u}}^{*}$ is the unemployed reservation wage. This reservation wage, $w_{\tau_{u}}^{*}$, is defined as

\footnotetext{
${ }^{5}$ For more details, see Devine and Kiefer (1991).
} 


$$
V_{e}\left(w_{\tau_{u}}^{*}\right)=V_{u}\left(b\left(\tau_{u}\right)\right)
$$

and it is easy to show that $w_{\tau_{u}}^{*}$ decreases monotonically until benefit termination.

Given knowledge of $\theta_{u}\left(\tau_{u}\right)$, it is easy to recover the unemployment duration density $g\left(\tau_{u}\right)$. That is

$$
g\left(\tau_{u}\right)=\frac{d\left(1-\exp \left(-\int_{0}^{\tau_{u}} \theta_{u}(s) d s\right)\right.}{d \tau_{u}}
$$

The escape rate out of the accepted job, $\theta_{e}\left(w_{a}\right)$, is independent of job tenure, $\tau_{e}$, but depends on the accepted wage, $w_{a}$, and is simply

$$
\theta_{e}\left(w_{a}\right)=\lambda_{e} \cdot\left\{1-F\left(w_{a}\right)\right\}
$$

As the re-employment wage depends on realized unemployment duration through the reservation wage, the mean accepted wage may be expressed as follows

$$
E\left(w_{a}\right)=\int_{0}^{\infty}\left[\int_{w_{\tau_{u}}^{*}}^{\infty}\left\{\frac{f(w)}{1-F\left(w_{\tau_{u}}^{*}\right)} w d w\right\}\right] \cdot g\left(\tau_{u}\right) d \tau_{u}
$$

where $f($.$) is the density of wage offers.$

Equation 2.1 illustrates how re-employment wages depend on unemployment duration through the reservation wage. In order to illustrate the Matching effect, it is convenient to look at the post-unemployment job duration survivor function conditional on unemployment (realized) duration. It is defined as

$$
\operatorname{Pr}\left(\tau_{e} \geq \tau \mid \tau_{u}\right)=S\left(\tau_{e} \mid \tau_{u}\right)
$$

Because both $\mathrm{V}_{e}(W)$ and $\theta_{e}\left(w_{a}\right)$ are independent from job tenure, the job duration survivor function is easy to derive. Bearing in mind that the distribution of observed wages depends on unemployment duration through the reservation wage, the conditional survivor function, $S\left(\tau_{e} \mid \tau_{u}\right)$, is the expected survivor function, $\operatorname{E} S\left(\tau_{e} \mid w\right)$, that is 


$$
\begin{array}{r}
\operatorname{Pr}\left(\tau_{e} \geq \tau \mid \tau_{u}\right)=S\left(\tau_{e} \mid \tau_{u}\right)=E_{w_{a}} S\left(\tau_{e} \mid w_{a}\right)= \\
\int_{w_{\tau_{u}}^{*}}^{\infty} \exp \left(-\tau_{e} \cdot \theta_{e}(s)\right)\left\{\frac{f(s)}{1-F\left(w_{\tau_{u}}^{*}\right)}\right\} d s
\end{array}
$$

While (2.1) establishes the negative relationship between unemployment duration and re-employment wages, (2.2) illustrates that declining reservation wages create a negative relationship between unemployment and subsequent job duration. Altogether, (2.1) and (2.2) illustrate the Matching effect of UI. As intuitive as it is, the matching effect of UI may turn out to be much weaker than what one would normally expect. In reality, UI is known to suffer from potential moral hazard problems. If a significant fraction of the unemployed use UI to finance household activities (including leisure), or search less intensively when entitled to more generous benefits, changes in the escape rate out of unemployment may be explained by changes in search intensity and it is not altogether clear that a matching effect of UI would prevail at all possible levels of unemployment duration. As well, and as mentioned above, Adverse Selection could also cause a spurious negative correlation between unemployment duration and subsequent job duration. For instance, if those individuals who have a low search intensity are also those who have a high propensity to quit their subsequent job, the negative correlation between unemployment and job duration would exist independently of the Matching effect. The need for a flexible estimation method, in which the true effect of benefit duration can be separated from Adverse Selection, is therefore quite obvious.

As is usually the case in applied econometrics, the investigator is faced with the option of estimating a fully structural version of the model or a reduced-form version. In the present case, it seems natural to model job match quality using data on accepted job duration and focus on a reducedform version of the model. First, modeling job and unemployment duration (as opposed to a fully specified structural model) will allow us to avoid making strong parametric assumptions about the key parameters of the model, such as the wage distribution. Second, as in most administrative data sets, re-employment wages are not fully reliable and are truncated beyond a certain level. Finally, modeling job and unemployment durations flexibly will avoid imposing smooth unemployment exit rates. Indeed, the sudden increase in the escape rate out of unemployment (usually present in US and in 
Canadian data) is difficult to capture in a structural dynamic programming model based on the rational expectation hypothesis. For all these reasons, I focus on the reduced-form version of the model and use the duration of the subsequent job as a measure of job match quality.

\section{The Canadian Unemployment Insurance Sys- tem}

The econometric model is estimated from a panel of Canadian labor force participants which is extracted from the Longitudinal Labor Force File of Employment and Immigration Canada. In what follows, I provide a brief discussion of the Canadian UI system. The Canadian Unemployment Insurance system (now called Employment Insurance) was established in 1940. As most UI systems in western countries, its fund is financed by premia collected from employers and employees. After having remained intact between 1940 and 1971, Canada's UI system was changed substantially in 1971. The increase in coverage and in the benefit rate, which took place in 1971-72, were substantial. At the same time, the maximum benefit period was extended and the minimum period of employment required to qualify for benefits was reduced. Although the 1971-72 changes were partially reversed by changes made between 1977 and 1979 (small reduction in the replacement ratio and in the maximum benefit duration, the Canadian UI system remained quite generous (compared to most US states) over the period of the current analysis.

As in many countries, the rules determining benefit duration in Canada are set by the government through a formula that depends on individual previous labor market history. Basically, those individuals who have worked more than a minimum number of weeks (10 to 14 weeks depending on the regional unemployment rate) can qualify for unemployment benefit. Unlike many US states, Canadian workers who quit their jobs are eligible for UI compensation. During the period covered by the data, those who quit their job could have been penalized for a period of 6 weeks. While the exogeneity of the maximum benefit period for job quitters can be questioned seriously, those individuals who have been laid off cannot influence the length of the benefit period once unemployed. As a consequence, it is reasonable to as- 
sume that, for those who have been laid off, maximum benefit duration is exogenous. Indeed, this is a standard assumption in the literature.

The analysis presented in this paper is based on a sample of young males who have experienced a layoff between January 1976 and February 1978. Over this period, the average benefit period was slightly decreased after changes to the UI regulations. This change took place in September 1977. In the sample used in this study, the difference in maximum benefit duration between those who have experienced job separation before September 77 and those after is around 3 weeks. ${ }^{6}$ For all those individuals who have experienced a layoff in between January 1976 and February 1978, the benefit rate has however remained constant at $66 \%$ of insurable earnings. The maximum insurable earnings are typically adjusted yearly to reflect changes in the average industrial salary. Over the sample period, individuals had to work between 10 to 14 weeks in order to qualify for benefit (depending on the regional rate of unemployment). The potential benefit duration is calculated from the number of weeks of employment over the 52 week period and the local rate of unemployment at the time. Except for those working in the fishing industry (excluded in this study), there are no variations in UI rules according to industry.

\section{The Data}

In this section, I describe the original data set and then explain the sampling method. The data are constructed as an event history data set and covers a period going from January 1972 until December 1984. It contain several pieces of information about employment and unemployment spells of a random sample of Canadian labor force participants. The data are actually based on a merge of several administrative files such as Records of Employment (ROE) and the Unemployment Insurance administrative files and they enable the researcher to recreate the sequence of labor market states occupied by a given individual. As is usually the case with administrative data, information on insured spells of unemployment (such as benefit durations and the weekly benefit level) are relatively accurate. However, the data are much less reliable when it comes to evaluating the labor market status of

\footnotetext{
${ }^{6}$ For an indepth analysis of the effects of the changes in legislation on both the duration and the incidence of unemployment, see Belzil (1995).
} 
those unemployed for a relatively long period, especially those unemployed beyond benefit termination.

The Records of Employment (ROE) identify the reason for separation and provide information about job tenure, age, experience and industry. In Canada, firms are legally required to issue a ROE for every job separation that takes place. The measure of experience available is the total number of weeks of employment from 1972 until 1984. It is therefore reliable for younger workers. The Unemployment Insurance file, along with some partial income tax records file, give information about potential benefit duration for the unemployed, weekly insurable earnings, unemployment duration, UI benefit level and the number of weeks of benefit entitlement left when a new job is accepted. The employer code available is used to identify individuals who have been laid off and returned with the same employer subsequently. The key UI variables are defined as follows;

- Initial (maximum) Benefit Duration: The maximum number of weeks of UI benefits that an individual can draw as recorded in the Unemployment Insurance File by the date of the formal application. It is calculated based on the number of weeks worked during the previous year, up to a certain maximum (around 45) which may depend itself on the local rate of unemployment. When an individual experiences a subsequent spell (under the same claim), initial benefit duration is reduced by the number of weeks used during the previous spell. Given the legislative changes and individual differences in previous employment and unemployment, there is substantial sample variation in initial entitlement at the beginning of a spell. For a few individuals in the sample, the maximum benefit duration is indeed 0 week. ${ }^{7}$ This is readily seen in the table reserved for summary statistics (Table 1). The mean initial benefit duration is 33 weeks but the standard deviation is 14 weeks.

- Potential benefit duration: The difference between maximum benefit duration and elapsed unemployment duration. When elapsed duration exceeds maximum benefit duration, potential benefit duration is set to 0 .

\footnotetext{
${ }^{7}$ For more details, see Ham and Rea (1987).
} 
- Benefit Level: The weekly benefits (measured in Canadian dollars) calculated from information on weekly insurable earnings.

\subsection{Sampling Method}

The data set used in this paper contains 2610 individual records of labor market histories for young males who have suffered a job separation between January 1976 and February 1978. Each individual was between 18 and 25 at the time of the job separation and was followed until 1984 through administrative records. Consequently, the number of spells attached to each records varies considerably across individuals. ${ }^{8}$ Out of these 2610 records, 1910 are coded as layoffs while 700 individuals quit to become unemployed.

As a first step, I retain the 1910 individuals who have experienced a layoff. As a second step, I exclude the 1001 cases where unemployment was followed by a job with the previous employer as well as the 700 individuals quo quit their job. This is because those individuals who returned to their previous employer are most likely to be on temporary layoffs and are likely to have a distinct search behavior from those who were displaced permanently. Those who quit their job are more likely to have a weaker attachment to the labor market. ${ }^{9}$ The resulting sample contains 909 individuals who have experienced an involuntary job separation. Most of these individuals (889 cases) have found a new job with a different employer while 20 of them have been lost by the UI authorities which means that I observe no subsequent job duration for these individuals. Given that reported unemployment duration is likely to be unreliable for these individuals, I censor unemployment duration at 50 weeks. In terms of the subsequent jobs, these 909 individual records are classified as followed;

- 464 subsequent job durations which were later terminated by a layoff

- 289 subsequent job durations terminated by a quit.

\footnotetext{
${ }^{8}$ Although the original file contains information on multiple unemployment and employment spells, for the current study, I only had access to a single unemployment and job spell per individual.

${ }^{9}$ Belzil (1995) has performed a separate analysis of those who are on temporary layoffs and found that the effect of UI benefit on unemployment duration and re-employment duration (unemployment incidence) differed substantially from the effects obtained for those individuals who accepted a new job.
} 
- 136 subsequent job spells still in progress as of 1984

- 20 cases where the unemployment spell is the last recorded state.

With administrative data, it is quite difficult to collect information on individuals who become non-participants. Among all individuals experiencing a layoff during this period (not only young workers), only $3.7 \%$ have actually left the accepted job to leave the labor force. However, as this information is actually estimated from the existence of subsequent employment record$\mathrm{s}$, this number can only be viewed as an estimate. As I look only at young males whom are well known to have a high turnover rate, only 15\% (136/909) are still employed with same employer at the end of 1984. To summarize, each individual contributes, at most, one unemployment duration-accepted job duration sequence. Some summary statistics are found in Table1. 


\section{Table 1}

\section{Some Sample Statistics}

Variable
Experience (weeks)
Previous Earnings (1977 dollars)
Duration of unemployment (weeks)
Maximum Benefit Period (weeks)
Potential Benefit period (at re-employment)
Unemployment Benefits ( 1977 dollars)
Previous Job Duration (weeks)
Accepted Earnings (current dollars)
Duration of Accepted job (weeks)
$\%$ in Primary Sector
$\%$ in Construction
$\%$ in Manufacturing
$\%$ in Transportation
$\%$ in Trade
$\%$ in Finance
$\%$ in Services
$\%$ in Administration

$\begin{array}{ll}\text { Mean } & \text { Stand. Dev. } \\ 127 & 61 \\ 240 & 120 \\ 14 & 18 \\ 33 & 14 \\ 6 & 3 \\ 122 & 30 \\ 22 & 29 \\ 223 & 102 \\ 35 & 65 \\ 7.1 & - \\ 7.2 & - \\ 18.7 & - \\ 11.0 & - \\ 13.6 & - \\ 11.2 & - \\ 15.4 & - \\ 15.3 & -\end{array}$

\section{Notes:}

- Earnings and unemployment benefits are measured in 1977 Canadian dollars.

- For the period over which job separation took place, the maximum benefit level was around $145 \$$ per week. 


\section{Econometric Specification: Disentangling True State Dependence from Spurious S- tate Dependence}

The analysis presented in this paper is based on a multi-state duration model which is used to estimate the effects of unemployment insurance benefit duration on subsequent job match quality (subsequent job duration). Job duration is defined as the waiting time until the subsequent job (following a spell of unemployment) is terminated voluntarily. The model has the following features;

- The distribution of subsequent job duration depends on completed unemployment duration (contiguous duration dependence) and the dependence is specified such that I can distinguish between a potential benefit duration effect and a general unemployment duration effect.

- The escape rate out of unemployment depends on the potential (remaining) benefit period (a time-varying co-variate).

- Unemployment duration and accepted job duration are stochastically related through unobserved heterogeneity.

\subsection{Modeling the Hazard Functions}

In order to estimate the effect of benefit duration on subsequent job duration I have to model two separate durations; unemployment duration and subsequent job duration. Because semi-parametric estimations of each hazard function would require the estimation of a very large number of parameters on top of the already large number of regression parameters which I have to estimate, I restrict myself to a parametric representation of the baseline hazard functions. I however estimate the distribution of the unobserved heterogeneity terms using a flexible method.

As a starting point, I model the hazard function for the duration of unemployment. This is the hazard function given maximum benefit duration $t_{v}$. At this stage, it is useful to discuss duration dependence. Duration dependence can arise because the data generating process implies duration dependence or because a co-variate is itself changing with elapsed duration. 
Simultaneously, spurious duration dependence in unemployment can also be caused by unobserved (neglected) heterogeneity. The specification of a hazard function where potential benefit duration changes every week will capture duration dependence in the search behavior of the unemployed caused by UI benefit exhaustion. Other duration effects will typically be captured in the baseline hazard.

I specify the unemployment hazard function as proportional hazards model with a time varying covariate (potential benefit duration) model and unobserved heterogeneity and a Weibull (rather than non-parametric) baseline hazard. ${ }^{10}$ Denoting unemployment duration (in continuous time) by $\tau_{u}$, letting $Z^{u}$ denote the set of time-invariant covariates and $X\left(\tau_{u}\right)$ the potential benefit duration at a given point in time, it is easy to see that

$\operatorname{Pr}\left(\tau_{u} \geq t_{u}+1 \mid \tau_{u} \geq t_{u}\right)=\exp \left\{-\exp \left(Z_{u}{ }^{\prime} \eta_{u}+\delta\left(X\left(t_{u}\right)\right) \cdot X\left(t_{u}\right)+\log \varepsilon^{u}+h_{0}^{*}\left(t_{u} ; \beta\right)\right)\right\}$

where $\mathrm{h}_{0}^{*}\left(t_{u} ; \beta\right)=\log \left(\left(t_{u}+1\right)^{\beta}-t_{u}^{\beta}\right)$ and $\beta$ is a parameter to be estimated. $X\left(t_{u}\right)$ is the difference between maximum benefit duration $\left(t_{v}\right)$ minus elapsed unemployment duration in discrete time $\left(t_{u}\right)$, that is

$$
X\left(t_{u}\right)=\operatorname{Max}\left(t_{v}-t_{u}, 0\right)
$$

The marginal effect of potential benefit duration on the unemployment hazard, $\delta\left(X\left(t_{u}\right)\right)$, is discussed in more details below. I assume that UI benefit entitlement changes between intervals (from one week to another) but remains constant within each interval (between $t_{u}$ and $t_{u}+1$ ). The vector of time invariant regressors $\left(Z_{u}\right)$ includes age (as measured at the start of the unemployment spell), experience and industrial classification.

For observations censored at $\mathrm{t}_{u}$,

$$
\operatorname{Pr}\left(\tau_{u} \geq t_{u}\right)=\prod_{s=1}^{t_{u}-1} \exp \left(-\exp \left(\mathrm{Z}_{u}{ }^{\prime} \eta_{u}+\delta(X(s)) \cdot X(s)+\log \varepsilon^{u}+h_{0}^{*}(s ; \beta)\right)\right)
$$

\footnotetext{
${ }^{10}$ Note that most theoretical models based on job search or job matching arguments predict that the job hazard rates are declining with tenure. Empirical evidence also suggests that job exit rates are declining with tenure (see Devine and Kiefer, 1991, for a survey).
} 
In the sample which I analyzed, the average potential benefit period is around 30 weeks while the maximum is 45 (for 7 individuals). Because UI officials report that recorded unemployment duration is likely to be inaccurate for those who have very long durations, I censor every duration at 50 weeks.

In order to take into account that the effect of a decrease in one week of benefit entitlement may change as benefit termination approaches, I estimate a more general specification where the effects of potential benefit period is allowed to vary over the duration of unemployment. This is accomplished using the following set of variables; $\mathrm{X}\left(\mathrm{t}_{u}\right), \mathrm{X}_{20-29}, \mathrm{X}_{10-19}, \mathrm{X}_{6-9}$ and $\mathrm{X}_{1-5}$. These variables are defined as follows;

$$
\begin{gathered}
X_{20-29}=X\left(t_{u}\right) \text { if } X\left(t_{u}\right) \leq 29 \text { and } 0 \text { if not } \\
X_{10-19}=X\left(t_{u}\right) \text { if } X\left(t_{u}\right) \leq 19 \text { and } 0 \text { if not } \\
X_{6-9}=X\left(t_{u}\right) \text { if } X\left(t_{u}\right) \leq 9 \text { and } 0 \text { if not } \\
X_{1-5}=X\left(t_{u}\right) \text { if } X\left(t_{u}\right) \leq 5 \text { and } 0 \text { if not }
\end{gathered}
$$

Altogether, these variables measure the remaining weeks of UI benefit at each point in the unemployment spell. With more than 29 weeks remaining, only potential benefit duration $\left(X\left(t_{u}\right)\right)$ takes non-zero values. When the number of weeks of UI benefit remaining lies between 20 and 29 , both $\mathrm{X}\left(\mathrm{t}_{u}\right)$ and $\mathrm{X}_{20-29}$ take non-zero values. As a similar argument is applied to the remaining segments ( 1 to 5 and 6-9), it follows that the marginal effect of a week of UI benefit is captured by summing the coefficients appropriately. As the potential benefit period decreases with elapsed unemployment duration, the marginal effect of an additional week of benefit represents the counterfactual effect of moving backward in time, away from benefit termination. It is given by

- $\delta$ when the current entitlement is between 30 and 50 weeks,

- $\delta+\delta_{20-29}$ when the current entitlement is between 20 and 29, 
- $\delta+\delta_{20-29}+\delta_{10-19}$ when the current entitlement is between 10 and 19 weeks,

- $\delta+\delta_{20-29}+\delta_{10-19}+\delta_{6-9}$ when the current entitlement is between 6 and 9 weeks

- $\delta+\delta_{20-29}+\delta_{10-19}+\delta_{6-9}+\delta_{0-5}$ within 5 weeks of benefit termination.

As an example, if the sum of all the coefficients from $\delta+\delta_{20-29}+\delta_{10-19}+$ $\delta_{6-9}+\delta_{0-5}$ is negative, this indicates that, within 5 weeks from benefit termination, the hazard decreases with each additional week of potential (remaining) benefit duration or, in other words, that the hazard increases as the individual approaches benefit termination. The effect of losing a week of benefit is therefore simply the opposite of the appropriate sum of the spline parameter estimates.

Finally, the last component of the model is subsequent job duration. As stated earlier, accepted job duration is understood as the waiting time until the individual quits the accepted job and is meant to measure the quality of the job match. Accepted job spells terminated by reasons other than a quit are considered as censored accepted job durations. This simply means that a job terminated by layoff was still acceptable to the worker. Given my objective to estimate the effects of UI benefit duration on accepted job duration, I must allow the accepted job hazard to depend on completed unemployment duration as well as a measure of benefit termination. I simply model accepted job duration using a proportional hazard with a Weibull baseline distribution. As I do with unemployment duration, I assume that recorded job duration takes discrete values which are generated from a continuous random variable, $\tau_{j}$, which hazard function is given by

$$
h_{j}\left(\tau_{j} \mid t_{u}, \varepsilon^{j}\right)=\exp \left(Z_{j}^{\prime} \eta_{j}+\zeta_{0} \cdot t_{u}+\zeta_{1} \cdot t_{u, 50}+\lambda \cdot X\left(t_{u}\right)+\log \varepsilon^{j}\right) \cdot \gamma \tau_{j}^{\gamma-1}
$$

where $Z_{j}$ is a vector of regressor including experience, age and industrial classification dummies. The effect of unemployment duration is measured by $t_{u}$ (when duration is below or equal to 50) and $t_{u, 50}$ (a binary variable equal to 1 for those unemployed more than 50 weeks) while $\mathrm{X}\left(\mathrm{t}_{u}\right)$ is the number of weeks of benefit left when the individual left unemployment to accept a new job. For instance, $\mathrm{X}\left(\mathrm{t}_{u}\right)$ is 0 for all those who found a job following benefit termination. 
In order to be more flexible, I can also allow the effect of benefit duration left to vary over the total benefit duration period and make use of the variables $\mathrm{X}(),. \mathrm{X}_{20-29}, \mathrm{X}_{10-19}, \mathrm{X}_{6-9}$ and $\mathrm{X}_{1-5}$ in order to obtain the ex-post effect of potential benefit duration on accepted job duration. The associated parameters are $\lambda, \lambda_{20-29}, \lambda_{10-19}, \lambda_{6-9}$ and $\lambda_{0-5}$. As for the unemployment hazards, the effects of potential benefit duration on accepted job hazards is measured by the sum of the appropriate coefficients.

\subsection{Constructing the Likelihood Function}

I construct the likelihood function as if exact spell lengths are unknown but I assume that the interval during which failure time takes place are known. The likelihood function can easily be constructed. If we assume that conditional on unobserved heterogeneity, unemployment duration and accepted job duration are independent, the likelihood function is simply the product of two individual densities. Noting that the number of accepted job spells (M) is smaller than the number of unemployment spells $(\mathrm{N})$, the 2 components are as follows

- Unemployment Duration

$$
\begin{aligned}
L_{u}\left(t_{u} \mid t_{v}, \varepsilon^{u}\right)=\prod_{i=1}^{N}\left[1-\exp \left(-\exp \left(Z_{u}^{\prime} \eta_{u}+\delta X\left(t_{u i}\right)+\log \varepsilon^{u}+h_{0}^{*}\left(t_{u i} ; \beta\right)\right)\right)\right]^{c_{i}^{u}} \\
\\
{\left[\prod_{s=1}^{t_{u i}-1} \exp \left(-\exp \left(Z_{u}^{\prime} \eta_{u}+\delta X(s)+\log \varepsilon^{u}+h_{0}^{*}(s ; \beta)\right)\right)\right] }
\end{aligned}
$$

The censoring indicator, $\mathrm{c}_{i}^{u}$, equals 1 if a spell is completed (between $\mathrm{t}_{u i}$ and $\mathrm{t}_{u i}+1$ ) and 0 if right censored.

- Accepted Job Duration

$$
\begin{aligned}
L_{j}\left(t_{j i} \mid\right. & \left.t_{v}, t_{u}, \varepsilon^{j}\right)= \\
& \prod_{i=1}^{M}\left[1-\exp \left(-\exp \left(Z_{j}^{\prime} \eta_{j}+\zeta_{0} \cdot t_{u}+\zeta_{1} \cdot t_{u, 50}+\lambda \cdot X\left(t_{u}\right)+\log \varepsilon^{j}+h_{0}^{*}\left(t_{j i} ; \gamma\right)\right)\right)\right]^{c_{i}^{j}} .
\end{aligned}
$$




$$
\left[\prod_{s=1}^{t_{j i}-1} \exp \left(-\exp \left(Z_{j}^{\prime} \eta_{j}+\zeta_{0} \cdot t_{u}+\zeta_{1} \cdot t_{u, 50}+\lambda \cdot X\left(t_{u}\right)+\log \varepsilon^{j}+h_{0}^{*}(s ; \gamma)\right)\right)\right]
$$

where $c_{i}^{j}$ is the censoring indicator for accepted job duration and is defined similarly as $\mathrm{c}_{i}^{u}$. Given these definitions, the conditional likelihood function, $\mathrm{L}\left(t_{u i}, t_{j i} \mid t_{v i}, \varepsilon^{u}, \varepsilon^{j}\right)$, is simply

$$
L\left(t_{u}, t_{j} \mid \varepsilon^{u}, \varepsilon^{j}, t_{v}\right)=L_{u}\left(t_{u} \mid \varepsilon^{u}, t_{v}\right) \cdot L_{j}\left(t_{j} \mid t_{v}, t_{u}, \varepsilon^{j}\right)
$$

\subsection{Unobserved Heterogeneity}

Estimation of the model by likelihood techniques requires that the individual unobserved heterogeneity terms be integrated out. In the paper, I consider the case where $\varepsilon^{u}$ and $\varepsilon^{j}$ follow a bi-variate discrete distribution and where both $\varepsilon^{u}$ and $\varepsilon^{j}$ have two points of support. The distribution is summarized as follows; $\operatorname{Pr}\left(\varepsilon^{u}=\varepsilon_{1}^{u}, \varepsilon^{j}=\varepsilon_{1}^{j}\right)=p_{1}, \operatorname{Pr}\left(\varepsilon^{u}=\varepsilon_{2}^{u}, \varepsilon^{j}=\varepsilon_{1}^{j}\right)=p_{2}, \operatorname{Pr}\left(\varepsilon^{u}=\varepsilon_{1}^{u}, \varepsilon^{j}=\right.$ $\left.\varepsilon_{2}^{j}\right)=p_{3}$ and $\operatorname{Pr}\left(\varepsilon^{u}=\varepsilon_{2}^{u}, \varepsilon^{j}=\varepsilon_{2}^{j}\right)=p_{4}$ for $\varepsilon_{1}^{u}>\varepsilon_{2}^{u}$ and $\varepsilon_{1}^{j}>\varepsilon_{2}^{j}$. In this case, 4 points of support and three free probabilities need to be estimated. The likelihood functions to be maximized is an average of 5.4 over all possible combinations of unobserved heterogeneity. In order to implement the model, I define the population proportions as logistic transforms. ${ }^{11}$ The model is estimated with the Maximum Likelihood application in Gaussi 3.2.26 on a Pentium 200. The log likelihood function is maximized using the BFGS and the BHHH algorithms.

\section{Empirical Results}

In this section, the empirical results are presented. The main parameter estimates and the marginal effects of approaching benefit termination are discussed in Section 6.1 while goodness of fit is discussed in Section 6.2.

\footnotetext{
${ }^{11}$ Standard errors for all p's can be obtained using the delta method. It can be shown that the correlation between $\varepsilon^{u}$ and $\varepsilon^{j}$ can be evaluated by the following expression;

$\operatorname{Corr}\left(\varepsilon^{u}, \varepsilon^{j}\right)=\frac{p_{1} p_{4}-p_{2} p_{3}}{\sqrt{\left(p_{1}+p_{3}\right)\left(p_{2}+p_{4}\right)\left(p_{1}+p_{2}\right)\left(p_{3}+p_{4}\right)}}$. It follows that the restriction needed to impose independence (a correlation of 0 ) between $\varepsilon^{u}$ and $\varepsilon^{j}$ is simply $q_{3}=q_{1}-q_{2}$. Testing for independence (given that $\varepsilon_{1}^{u} \neq \varepsilon_{2}^{u}$ and $\varepsilon_{1}^{j} \neq \varepsilon_{2}^{j}$ ) can be achieved with a likelihood ratio statistic which has a $\chi_{1}^{2}$ distribution under the null hypothesis.
} 


\subsection{The Relationship between Potential Benefit Dura- tion and Subsequent Job Duration}

The main parameter estimates are found in Table 2. I present two set of estimates; those obtained when past earnings are introduced (column 1) and those obtained when it is omitted (column 2). I do so because previous earnings are possibly correlated with unobserved heterogeneity. ${ }^{12}$ The effect of previous earnings on the exit rate out of unemployment is found to be positive (0.38) and indicates that, other things equal, those with higher preunemployment earnings leave unemployment faster. ${ }^{13}$ The effect of benefit level is negative $(-0.28)$ and indicates that, all else equal, those receiving higher level of benefits tend to leave unemployment later. Both results are standard in the literature. The estimate for $\beta$ (0.93) indicates the presence of negative duration dependence (the hazard function decreases with elapsed unemployment duration).

As has been found in the literature, the effect of potential benefit duration (captured in the $\delta$ 's) varies with the level of potential benefit duration. The spline estimates are $-0.31\left(\delta_{0-5}\right),-0.20\left(\delta_{6-9}\right),-0.06\left(\delta_{10-19}\right), 0.01\left(\delta_{20-29}\right)$ and $-0.03(\delta)$. Only $\delta_{0-5}, \delta_{6-9}$ and $\delta_{10-19}$ are significantly different from 0 . In order to facilitate the understanding of the spline estimates, I have summarized the marginal effects of approaching benefit exhaustion for all ranges considered. In order to illustrate the effect of moving closer to benefit termination, the sum of all appropriate parameters is multiplied by -1 . These marginal effects are found in Table 3. There is clear evidence that before 19 weeks from benefit termination, potential benefit duration has practically no impact on unemployment hazards. With 10 to19 weeks of benefit left, losing an additional week (approaching benefit termination by one week) raises the hazard by 0.08 while between 6 to 9 weeks, the increase is 0.27 . The effect is particularly strong within 5 weeks from benefit termination; the hazard increases by 0.58 for each additional week.

The flexible specification of the effect of benefit duration on accepted job duration (with $\lambda, \lambda_{20-29}, \lambda_{10-19}, \lambda_{6-9}$ and $\lambda_{0-5}$ ) allows me to compare the exit rate out of the subsequent job at various levels of potential benefit du-

\footnotetext{
${ }^{12}$ The parameter estimates for age, experience and industry dummy regressors can be found in Belzil (2000).

${ }^{13} \mathrm{I}$ also use a binary variable for the case where previous earnings are top coded (equal to the maximum insurable earnings).
} 
ration left when the new job was accepted. The spline estimates (found in Table 2) are $-0.02\left(\lambda_{0-5}\right),-0.04\left(\lambda_{6-9}\right),-0.01\left(\lambda_{10-19}\right), 0.00\left(\lambda_{20-29}\right)$ and 0.01 $(\lambda)$. In general, they are less significant than the unemployment duration spline estimates. While only $\lambda_{0-5}$ and $\lambda_{6-9}$ appear reasonably significan$\mathrm{t}$, a likelihood ratio test for the joint significance of the spline estimates $\left(\lambda_{0-5} \ldots=\ldots \lambda_{20-29}=0\right)$ is rejected at the $5 \%$ level (the p-value is 0.05$) .{ }^{14}$ The spline estimates are therefore jointly significant. Similar to the unemployment hazards, I have transformed the spline estimates into marginal effects of approaching benefit termination on accepted job hazards. These estimates, also found in Table 3, can be used to investigate the importance of the Matching effect at various ranges of potential benefit duration. Overall, I find a pattern relatively similar to the one observed for the unemployment hazards; the effect of potential benefit is positive and stronger around benefit termination. However, the parameter estimates are generally much lower (in absolute values) than the effect of potential benefit duration on unemployment hazards. The Matching effect is practically non-existent until the individual is left with less than 9 weeks of benefit duration. Within 6 to 9 weeks of benefit termination, every week of benefit lost translates into an increase of 0.0392 in the accepted job hazard (as summarized in Table 3). Within 5 weeks, the effect is 0.0639 . After controlling for benefit duration, the effect of an additional week of unemployment on subsequent job hazard$\mathrm{s}$ is positive (0.0256) but insignificant. While the evidence in favor of the Matching effect appears relatively weak, the importance of unobserved heterogeneity is well illustrated by the significance of the correlation estimate. I find the correlation between unemployment duration and subsequent job duration unobserved heterogeneity to be -0.60 and the asymptotic t-ratio is larger than 10. This should be taken as evidence that those who tend to experience longer spells of unemployment are also those who tend to experience shorter job spells. The parameter estimate for $\left(\zeta_{0}\right)$ is positive $(0.03)$ but insignificant and indicates that, after conditioning on benefit duration, unemployment duration has no significant effect on subsequent job hazards. Finally, the scale parameter of the subsequent job hazard function $(\gamma=0.85)$ indicates negative duration dependence.

The estimates in column 2 are those obtained when previous earnings are included. Overall, the results appear unaffected by the exclusion of previous

\footnotetext{
${ }^{14}$ The parameter estimates obtained under the null hypothesis are found in Belzil (2000).
} 
earnings. A decrease in potential benefit duration increases the unemployment hazard by a factor 0.61 between 0 to 5 weeks from benefit termination, by a factor of 0.28 between 6 and 9 weeks, and by 0.08 between 10 and 19 weeks from benefit termination. However, benefit duration does not seem to matter really when individuals are more than 19 weeks away from benefit termination. As in the model with previous earnings, the estimates of the effect of potential benefit duration on subsequent job hazards indicate that most of the matching effects of UI benefits are located within 10 weeks from benefit exhaustion; the marginal effect is around 0.06 within 5 weeks from benefit termination and 0.03 between 6 and 9 weeks. Beyond 9 weeks, the spline estimates imply very low marginal effects and, as a consequence, there is practically no Matching effect. The test for the joint significance of $\lambda_{1-5}, \lambda_{6-9}, \lambda_{10-19}$ and $\lambda_{20-29}$ rejects the null hypothesis at $5 \%$ and indicates that there is a significant matching effect (the p-value is 0.042).

To summarize, I find some support for a positive effect of unemployment benefit duration on subsequent job match quality. However, the results also indicate that the effects of benefit duration on unemployment hazards and accepted job hazards are located mostly within 5 weeks of benefit termination. When individuals are more than 10 weeks away from benefit exhaustion, potential UI benefit duration has virtually no effect on subsequent job duration. It should also be noted that in the short interval over which I find a Matching effect of UI benefit duration, job hazards are much less sensitive to benefit termination than unemployment hazards. At the same time, I find strong evidence of a negative (and significant) correlation between unemployment duration and job duration. There is therefore much support for the Adverse Selection hypothesis.

\subsection{Goodness of Fit}

As is commonly done in applied microeconometrics, empirical frequencies (unemployment and subsequent job durations) can be compared to predicted frequencies in order to evaluate the relevance of the model. This is particularly important in a framework where the baseline distribution is estimated using parametric methods. The unemployment duration frequencies are in Table $4 \mathrm{~A}$ and the subsequent job duration frequencies are in Table 4B. A comparison between actual and predicted unemployment duration frequen-

cies indicates that the model fits unemployment duration quite well. This 
is most likely explained by the flexible specification of the effect of benefit duration. While the predicted subsequent duration frequencies appear to be below actual job duration frequencies at short duration and exceed actual frequencies at long duration, the goodness of fit is still reasonably good. 
Table 2

\section{Parameter Estimates}

(1)

Unemp. duration

Log Earnings

Benefit level $(\log )$

Duration Dependence $(\beta)$
-

$0.3822(2.88) \quad-$

$-0.2834(3.01) \quad-0.2935(2.92)$

$0.9256(6.68) \quad 0.9221(6.58)$

Remaining Benefit Duration

$\delta_{(1-5)}$

$\delta_{(6-9)}$

$\delta_{(10-19)}$

$\delta_{(20-29)}$

$\delta$

Unobs. heterogeneity

$\varepsilon_{1}^{u}$

$\varepsilon_{2}^{u}$

$\varepsilon_{1}^{j}$

$\varepsilon_{2}^{j}$

$\mathrm{P}_{1}$

$\mathrm{P}_{2}$

$\mathrm{P}_{3}$

$\operatorname{Corr}\left(\varepsilon^{u}, \varepsilon^{j}\right)$

$$
-0.3076(3.01) \quad-0.3325(2.64)
$$$$
-0.1978(2.27) \quad-0.2032(2.36)
$$$$
-0.0567(2.02) \quad-0.0612(1.93)
$$$$
0.0126(1.18) \quad 0.0139(0.85)
$$$$
-0.0307(0.83) \quad-0.0298(0.56)
$$

$$
0.5387(2.89) \quad 0.5832(3.12)
$$

$0.3628(2.28) \quad 0.3394(2.42)$

$0.3923(3.18) \quad 0.3623(2.90)$

$0.2638(2.02) \quad 0.2341(1.79)$

$0.0645(2.00) \quad 0.0589(1.83)$

$0.3745(2.57) \quad 0.4005(3.24)$

$0.3834(3.04) \quad 0.3905(2.36)$

$-0.6020(10.03) \quad-0.6201(9.63)$ 
Table 2- Continued

(1)

(2)

Accepted job duration

Duration Dependence $(\gamma)$

$0.8471(4.24) \quad 0.8395(5.15)$

Unemp. Duration $\left(\zeta_{0}\right) \quad 0.0256(1.68) \quad 0.0200(1.68)$

Unemp. $\operatorname{Dur}_{50}\left(\zeta_{1}\right) \quad 0.2015(1.67) \quad 0.1956(1.74)$

Benefit Duration Left

$\lambda_{X(1-5)}$

$\lambda_{X(6-9)}$

$-0.0247(1.88) \quad-0.0327(1.90)$

$\lambda_{X(10-19)}$

$\lambda_{X(20-29)}$

$-0.0393(1.68)-0.0356(1.65)$

$\lambda_{X\left(t_{u}\right)}$

$-0.0067(1.02) \quad-0.0074(1.39)$

$0.0012(0.57) \quad 0.0059(0.95)$

$0.0056(0.89) \quad 0.0059(0.78)$

Log likelihood $\quad-1343.9 \quad-1348.0$

\section{Notes:}

Asymptotic t-ratios in parentheses.

The p-value for the likelihood ratio test for the null that $\lambda_{X(1-5) .} . . . . \lambda_{X(20-29)}=$ 0 is 0.0531 in column 1 and 0.042 in column 2. Estimates obtained under the null hypothesis can be found in Belzil (2000). 
Table 3

The Marginal Effects of Approaching Benefit Termination on Unemployment and Subsequent Job Hazards

(1) Unemp. Hazards
Prev. Earnings included excluded included excluded
(2)

Unemp Hazards
(3)

Sub. Job Sub. Job

Hazards Hazards
Weeks of

Benefit Left

$0-5$

6-9

$10-19$

$20-29$

$30-50$
0.5812

0.2736

0.0758

0.0181

0.0307
0.6128

0.2803

0.0771

0.0159

0.0298
0.0639

0.0392

$-0.0001$

$-0.0068$

$-0.0056$
0.0627

0.0300

$-0.0056$

$-0.0118$

$-0.0059$

Note: The marginal effects of approaching benefit termination, found in column 1 and column 2, represent the effect of losing an additional week of potential benefit duration on unemployment hazards. The marginal effects of approaching benefit termination, found in column 3 and column 4, represent the effect of losing an additional week of potential benefit duration on accepted job hazards. Both of them are computed using the appropriate sum of the spline estimates (the $\delta^{\prime} s$ and the $\lambda^{\prime} s$ ). 
Table 4A

Goodness of Fit: Unemployment Duration

(1)

predicted

freqencies freqencies
(2)

actual

rercos

Weeks

$\begin{array}{lll}\mathbf{1 - 4} & 0.43 & 0.40 \\ \mathbf{5 - 8} & 0.15 & 0.13 \\ \mathbf{9 - 1 2} & 0.07 & 0.08 \\ \mathbf{1 3 - 1 6} & 0.05 & 0.06 \\ \mathbf{1 7 - 2 0} & 0.03 & 0.05 \\ \mathbf{2 1 - 2 4} & 0.03 & 0.04 \\ \mathbf{2 5 - 2 8} & 0.02 & 0.02 \\ \mathbf{2 9 - m o r e} & 0.20 & 0.12\end{array}$

Table 4B

Goodness of Fit: Subsequent Job Duration

(1)

predicted

frequencies frequencies

(2)

actual

Weeks

$\begin{array}{lll}\mathbf{1 - 1 0} & 0.16 & 0.19 \\ \mathbf{1 1 - 2 0} & 0.13 & 0.17 \\ \mathbf{2 1 - 3 0} & 0.15 & 0.15 \\ \mathbf{3 1 - 4 0} & 0.09 & 0.08 \\ \mathbf{4 1 - 5 0} & 0.05 & 0.06 \\ \mathbf{5 1 - 6 0} & 0.05 & 0.04 \\ \mathbf{6 1 - 7 0} & 0.05 & 0.03 \\ \mathbf{7 1 - m o r e} & 0.32 & 0.28\end{array}$




\section{The Effects of Benefit Duration on Unem- ployment and Accepted Job Durations: Some Simulations}

At this stage, it seems natural to investigate the effects of increasing maximum benefit duration. I have performed simulations for two different types of individual; one entitled to 25 weeks and one entitled to 45 weeks. In both cases, I have computed the increase in mean unemployment duration and mean accepted job duration following an increase of 1 week in maximum benefit duration. I have performed those simulations for both model specifications reported in the paper.

Overall, the results indicate that the unemployment duration elasticity ranges from 0.15 and 0.20 . In terms of weeks, these estimates indicate that increasing potential benefit duration by an additional week will increase mean unemployment duration by 1.5 to 1.1 days $^{15}$. The effects of benefit duration on accepted job durations are smaller. The elasticities range from 0.10 to 0.13 . Increasing potential benefit duration by 1 week will increase mean job duration by less than 1 day; the increase in job duration ranges from 0.5 to 0.8 days. Although the effect of an increase in benefit duration might appear weak, one should bear in mind that the parameter estimates indicate that the matching effect is located mostly at the end of the benefit period. As a consequence, for all those leaving unemployment with a potential benefit duration superior to 5 weeks, an increase in benefit duration has virtually no impact on the subsequent job hazard rate. To summarize, although both the unemployment duration and accepted job duration effects of an increase in benefit duration are small, the increase in unemployment duration is higher than the increase in accepted job duration. The negative effects of benefit duration therefore tend to dominate the positive effects. ${ }^{16}$

\footnotetext{
${ }^{15}$ The effects of benefit duration on unemployment duration appear consistent with simulation results reported by various authors. For instance, Ham and Rea (1987) report that an increase of 1 week in benefit duration increases unemployment duration by 0.16 to 0.20 week. For a review, see Devine and Kiefer (1991). As far as I know, the effect of benefit duration on job duration cannot be compared to any study.

${ }^{16}$ All the results reported previously are based on the hypothesis that the matching effects of UI benefits are measured by the waiting time until an individual will quit the post unemployment job. In order to check the robustness of the results to the definition of a job termination, I have extended the analysis to the case where accepted job duration
} 


\title{
Table 6
}

\section{Simulating the Effects of an Increase in Benefit Duration}

\author{
(1) \\ (2) \\ $\frac{\Delta \% \text { Unemp.Duration }}{\Delta \% \text { Benefit.Duration }}$ \\ (3) \\ (4) \\ Ben. dur \\ 25 weeks 45 weeks \\ $\frac{\Delta \% \text { Job.Duration }}{\Delta \% \text { Benefit.Duration }}$ \\ 25 weeks 45 weeks
}

Table 3, col 1

0.19

0.16

0.13

0.11

Table 3, col 2

0.20

0.15

0.13

0.10

Note: Simulations have been computed at the maximum benefit duration of 25 weeks and 45 weeks.

\section{Conclusion}

It is generally considered that UI benefit generosity induces those who have lost their job to remain unemployed for longer periods. The effects of UI benefit generosity on the quality of post-unemployment labor market adjustments are however not as clear. In this paper, I have tried to measure the effects of potential UI benefit duration on the quality of subsequent job matches and investigated whether the correlation between completed unemployment duration and subsequent job duration is explained by Job Matching or by Adverse Selection.

Overall, I find the Job Matching effect to be weak. While there is a structural effect of benefit duration taking place shortly before benefit termination, the negative correlation between unemployment and job duration

is defined as the waiting time until the accepted job is terminated either by a layoff or a quit. This can be justified by the fact that the distinction between quits and layoffs can sometimes be insignificant. Despite the fact that accepted job duration is re-defined, the changes in the estimates of benefit duration on the accepted job duration hazard function are quite marginal. The resulting elasticities (ranging between 0.08 and 0.11 ) indicate that an increase of 1 week in benefit duration will increase accepted job duration by 0.4 to 0.8 day. More details can be found in Belzil (2000). 
is mostly explained by Adverse Selection. As a consequence, raising unemployment benefit duration will only have a marginal effect on subsequent job duration. The results of various simulations indicate that increasing the maximum benefit duration by one week will raise expected unemployment duration by 1.0 to 1.5 days but expected job duration by 0.5 to 0.9 days only.

It is well known that an increase in unemployment hazards can be explained by an increase in search effort, a decrease in reservation wages or by implicit recall arrangements between workers and firms. Since workers returning to the same employer are eliminated from the sample, the larger sensitivity of unemployment hazards to benefit termination, when compared to subsequent job hazards, seems to indicate that reservation wages do not drop substantially. Perhaps, the increase in unemployment hazards is explained mostly by an increase in search effort. At the same time, the strong negative correlation between unemployment duration heterogeneity and accepted job duration heterogeneity is harder to explain. As unobserved heterogeneity is meant to capture the effects of all omitted characteristics on unemployment and job duration outcomes, giving a structural interpretation to the negative correlation (after controlling for benefit duration) can be seen as hazardous. As stated before, Adverse Selection is one of the potential interpretation of the strong negative correlation between unemployment duration and subsequent job duration. If individuals, who have a strong taste for leisure or household production, tend to exhaust their benefits and accept jobs that last long enough to re-qualify for UI benefits, the data would certainly exhibit negative correlation between unemployment job duration and accepted job duration. As search effort is inherently unobservable, this type of sorting effect is probably unavoidable. This suggests an avenue for future research. Structural job search models, which are estimated from micro-data and based on the maintained hypothesis that individuals start searching once they have lost their job, should perhaps be modified to take into account that household production (or leisure) is a substitute to job search activities.

\section{References}

Belzil, Christian (1995) "Unemployment Insurance and Unemployment Over

Time: An Analysis with Event History Data" The Review of Economics and 
Statistics, vol 77, April 1995, 113-126.

Belzil, Christian (1990) "Unemployment Insurance, Unemployment and Labour Market Transitions: An Empirical Analysis with Canadian Data" Unpublished Doctoral Dissertation, Graduate School, Cornell University.

Classen, K.P. (1977) "The Effects of Unemployment Insurance on the Duration of Unemployment and Subsequent Earnings" Industrial and Labor Relations Review 30 (8):438-444.

Devine, Theresa and Kiefer, Nicholas M. (1991) Empirical Labor economics: The Search Approach. Oxford University Press, New York

Ehrenberg R.G. and Ronald Oaxaca (1976) "Unemployment Insurance, Duration of Unemployment and Subsequent Wage Gain" American Economic Review 66: 754-766.

Han, Aaron and Hausman, Jerry (1990) "Flexible Parametric Estimation of Duration and Competing Risk Model". Journal of Applied Econometrics, 5, :325-353.

Ham, John and Rea, Samuel (1987) "Unemployment Insurance and Male Unemployment Duration in Canada", Journal of Labor Economics, 5 (3):32553.

Hopenhayn, Hugo and Juan Pablo Nicolini (1997) "Optimal Unemployment Insurance", Journal of Political Economy" , 105 (2): 412-38.

Meyer, Bruce (1990) "Unemployment Insurance and Unemployment Spells", Econometrica, 58 (4): 757-782. 


\section{Liste des publications au CIRANO *}

\section{Cahiers CIRANO / CIRANO Papers (ISSN 1198-8169)}

99c-1 Les Expos, l'OSM, les universités, les hôpitaux : Le coût d'un déficit de 400000 emplois au Québec - Expos, Montréal Symphony Orchestra, Universities, Hospitals: The Cost of a 400,000-Job Shortfall in Québec / Marcel Boyer

96c-1 Peut-on créer des emplois en réglementant le temps de travail? / Robert Lacroix

95c-2 Anomalies de marché et sélection des titres au Canada / Richard Guay, Jean-François L'Her et Jean-Marc Suret

95c-1 La réglementation incitative / Marcel Boyer

94c-3 L'importance relative des gouvernements : causes, conséquences et organisations alternative / Claude Montmarquette

94c-2 Commercial Bankruptcy and Financial Reorganization in Canada / Jocelyn Martel

94c-1 Faire ou faire faire : La perspective de l'économie des organisations / Michel Patry

\section{Série Scientifique / Scientific Series (ISSN 1198-8177)}

2001s-20 Estimating the Intergenerational Education Correlation from a Dynamic Programming Model / Christian Belzil et Jörgen Hansen

2001s-19 The Bootstrap of the Mean for Dependent Heterogeneous Arrays / Sílvia Gonçalves et Halbert White

2001s-18 Perspectives on IT Outsourcing Success: Covariance Structure Modelling of a Survey of Outsourcing in Australia / Anne C. Rouse, Brian Corbitt et Benoit A. Aubert

2001s-17 A Theory of Environmental Risk Disclosure / Bernard Sinclair-Desgagné et Estelle Gozlan

2001s-16 Marriage Market, Divorce Legislation and Household Labor Supply / Pierre-André Chiappori, Bernard Fortin et Guy Lacroix

2001s-15 Properties of Estimates of Daily GARCH Parameters Based on Intra-Day Observations / John W. Galbraith et Victoria Zinde-Walsh

2001s-14 A Ricardian Model of the Tragedy of the Commons / Pierre Lasserre et Antoine Soubeyran

2001s-13 Carbon Credits for Forests and Forest Products / Robert D. Cairns et Pierre Lasserre

2001s-12 Estimating Nonseparable Preference Specifications for Asset Market Participants / Kris Jacobs

2001s-11 Autoregression-Based Estimators for ARFIMA Models / John W. Galbraith et Victoria Zinde-Walsh

2001s-10 Heterogeneous Returns to Human Capital and Dynamic Self-Selection / Christian Belzil et Jörgen Hansen

\footnotetext{
* Consultez la liste complète des publications du CIRANO et les publications elles-mêmes sur notre site Internet :
} 